\title{
Hydrolysis of caprine and ovine milk proteins, brought about by aspartic peptidases from Silybum marianum flowers
}

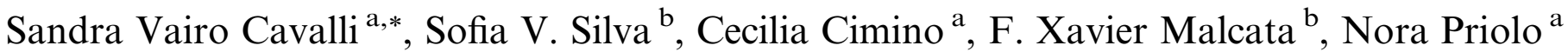 \\ ${ }^{a}$ LIPROVE, Departamento de Ciencias Biológicas, Faculated de Ciencias Exactas, UNLP, CC 711, 1900 La Plata, Argentina \\ ${ }^{\mathrm{b}}$ Escola Superior de Biotecnologia, Universidade Católica Portuguesa, Rua Dr. António Bernardino de Almeida, P-4200-072 Porto, Portugal
}

Received 28 March 2007; received in revised form 15 June 2007; accepted 10 July 2007

\begin{abstract}
The flowers of cardoon (Asteraceae) are a rich source of aspartic peptidases which possess milk clotting activity - and are thus used in traditional cheesemaking in the Iberian Peninsula. This study was aimed at characterizing the enzymatic action of the aspartic peptidases present in flowers of Silybum marianum (L.) Gaertn. (Asteraceae), specifically upon degradation of caseins. The proteolytic activities toward Na-caseinates previously prepared from caprine and ovine milks were studied, in a comparative fashion, using urea-PAGE, tricine-SDS-PAGE, densitometry, electroblotting and sequencing. Caprine $\alpha_{\mathrm{s} 1}$ - and $\beta$-caseins were degraded up to $68 \%$ and $40 \%$, respectively, during $24 \mathrm{~h}$ of incubation. Only one important and well-defined band corresponding to a molecular weight of $14.4 \mathrm{kDa}-$ i.e. a fragment of $\beta$-casein, was observed by $12 \mathrm{~h}$ of hydrolysis. By $24 \mathrm{~h}$ of incubation, ovine $\alpha_{\mathrm{s}^{-}}$and $\beta$-caseins were degraded up to $76 \%$ and $19 \%$, respectively. In what concerns specificity, the major cleavage site in ovine caseinate was Leu99-Arg100 in $\alpha_{\mathrm{s} 1}$-casein.
\end{abstract}

(c) 2007 Elsevier Ltd. All rights reserved.

Keywords: Rennet substitute; Proteolysis; Electrophoresis; Aspartic peptidase; Milk clotting

\section{Introduction}

Argentina is the second milk producer of Latin America, and it ranks eleventh place on a world-wide basis. Sales of goat's and ewe's milk cheeses appears to be an attractive alternative to reconvert and diversify primary production in that country, since possesses a relation of favorable price of 3:1 when compared with cheeses of bovine origin (Dayenoff, Ochoa, \& Domínguez, 2002; Estación Experimental Agropecuaria Chubut, 2006). Furthermore, goats and ewes can grow in more unfavorable environmental conditions, from a feeding point of view, than cows (Dayenoff et al., 2002). On the other hand, cheeses manufactured from milk of ewes or goats possess a much higher added value as gourmet products are in stake.

\footnotetext{
* Corresponding author. Tel.: +54 221 4230121x57; fax: +54 221422 6947.

E-mail address: svairo@biol.unlp.edu.ar (S. Vairo Cavalli).
}

The unique nutritional composition relative to cow's milk should also be emphasized. This reflects especially in cheese yield: ca. 5.51 of ewe's milk is required to produce $1 \mathrm{~kg}$ of cheese, whereas ca. 111 of cow's milk is required for the same amount of cheese. This greater cheese yield is explained by the quantitatively higher content of fat $(7.5 \%)$ and caseins $(4.6 \%)$ of ewe's milk than cow's counterpart (3.9\% of fat and $2.6 \%$ of caseins); a similar realization holds with goat's milk ( $4.5 \%$ of fat and $3.0 \%$ of caseins). In addition to the aforementioned higher cheese yield, goat's and ewe's milk have beneficial health properties, because of their mineral and vitamin levels, and their different protein profile (Walstra, Geurts, Noomen, Jellema, \& van Boekel, 1999; Dulce, 2006).

Aqueous extracts from flowers of Cynara cardunculus (Veríssimo, Esteves, Faro, \& Pires, 1995; Veríssimo et al., 1996), Cynara humilis, and/or Cynara scolymus contain proteinases, so thus have accordingly been used in the Iberian Peninsula since Roman times to manufacture ovine and/ or caprine milk cheeses (Reis et al., 2000). Milk clotting 
activity was also found in flowers of Centaurea calcitrapa, Onopordum turcicum and Silybum marianum (Domingos et al., 1998; Tamer, 1993; Vairo Cavalli, Claver, Priolo, \& Natalucci, 2005). All these species belong to the Asteraceae family, and furthermore lie in the same tribe: Cardueae Cass. = Cynareae Less. (Ariza-Espinar \& Delucchi, 1998). Flowers specifically of $S$. marianum were claimed to contain aspartic proteinases that were able to entertain milk clotting; such clotting activity is partially inhibited at $\mathrm{NaCl}$ concentrations above $50 \mathrm{mM}$, whereas the effect of $\mathrm{CaCl}_{2}$ is biphasic - with an initial decrease, followed by an increase in rennet clotting times (Vairo Cavalli et al., 2005).

Primary proteolysis is caused chiefly by residual rennet, and produces large to medium-sized peptides from the starting caseins; these can be further degraded into small peptides, and eventually free amino acids - in a process generally known in whole as secondary proteolysis. Primary proteolysis plays an essential role upon development of proper cheese texture, whereas secondary proteolysis is often implicated with cheese flavour; it is thus of great importance to assure a well-balanced breakdown of caseins, in order to prevent development of such undesired attributes in cheese as low viscosity and high bitterness (Visser, 1993). Proteolysis is indeed the most important set of biochemical transformations during cheese ripening, in which the residual rennet plays a relevant role; hence, it is of the utmost importance to evaluate the degradation patterns of caseins in model systems that mimic actual cheesemaking (Irigoyen, Izco, Ibáñez, \& Torre, 2000; Silva \& Malcata, 1999).

Analysis of the degradation pattern of bovine Na-caseinate by aspartic proteinases from $S$. marianum was studied previously - and was even considered as a new source of plant rennet, with distinctive, useful characteristics for the dairy industry (Vairo Cavalli et al., 2005). The aim of this work was to complement that knowledge, via evaluating the action of those aspartic peptidases upon the hydrolysis of caprine and ovine Na-caseinates - using experimental conditions that parallel milk $(\mathrm{pH} 6.5)$, in order to address an increasing worldwide demand for alternative dairy products with improve organoleptic nutritional and health properties. Study of casein breakdown in model systems will likely generate important information to help elucidate the complex processes involved in ripening of cheeses from small ruminants, and eventually contribute toward development of better, non conventional final cheeses (Silva \& Malcata, 2000).

\section{Materials and methods}

\subsection{Enzyme extract preparation}

The method described by Vairo Cavalli et al. (2005) was followed to prepare the enzyme extract. Fresh flowers of $S$. marianum (L.) Gaertn. were ground with a mortar and pestle under liquid nitrogen, homogenized at a ratio of $1 \mathrm{~g}$ per $3 \mathrm{ml}$ of $0.1 \mathrm{M}$ citric acid-sodium citrate buffer $(\mathrm{pH} 3.0)$ containing $1.0 \mathrm{mM}$ EDTA, and stirred for $30 \mathrm{~min}$. The homogenate was centrifuged at $5000 \mathrm{~g}$ for $20 \mathrm{~min}$ at $4{ }^{\circ} \mathrm{C}$, and a $10-\mathrm{ml}$ aliquot of the supernatant was applied to a Pharmacia K 15/30 column packed with a size exclusion chromatographic medium (Sephadex G-25 Fine, from GE Healthcare, Uppsala, Sweden) - which had been previously equilibrated with $50 \mathrm{mM}$ citric acid-sodium citrate buffer ( $\mathrm{pH}$ 3.0). Elution was performed with the same buffer, at a $0.45 \mathrm{ml} / \mathrm{min}$ flow rate, so as to obtain a partially purified enzyme extract (EE).

\subsection{Protein quantification}

Protein concentration was determined by the method of Bradford (1976). Bovine serum albumin (Sigma, St. Louis MO, USA) was used as reference in the preparation of the calibration curve.

\subsection{Milk clotting activity}

A $100 \mu$ l-aliquot of EE was added to $1 \mathrm{ml}$ of skim milk (San Regim, SanCor, Argentina) and 12\% (w/v) in $10 \mathrm{mM}$ $\mathrm{CaCl}_{2}$, at $30^{\circ} \mathrm{C}$ (Vairo Cavalli et al., 2005). The milk clotting activity (MCA) was measured following the procedure described by the International Dairy Federation (1992). One rennet unit (RU) was defined as the amount of enzyme that coagulates $10 \mathrm{ml}$ of milk at $30^{\circ} \mathrm{C}$ in $100 \mathrm{~s}$ (Barros, Ferreira, Silva, \& Malcata, 2001).

\subsection{Endopeptidasic activity}

The endopeptidasic activity of the EE was determined by hydrolysis of the synthetic fluorogenic peptide MCALys-Pro-Ala-Glu-Phe-Phe-Ala-Leu-DNP (Genosphere Biotechnologies, Paris, France), according to Veríssimo et al. (1996) with modifications. Enzyme preparations were incubated at $37^{\circ} \mathrm{C}$ with $0.54 \mu \mathrm{g} / \mathrm{ml}$ of substrate in $50 \mathrm{mM}$ Na-acetate buffer ( $\mathrm{pH}$ 5.6), containing $140 \mathrm{mM} \mathrm{NaCl}$. The rate of hydrolysis of the aforementioned Phe-Phe bond was monitored for $5 \mathrm{~min}$, in a thermostated spectrofluorometer Luminiscence Spectrometer LS 50 B (Perkin Elmer, Wellesley MA, USA). The fluorofore was excited at $328 \mathrm{~nm}$, and the light emitted was detected at $393 \mathrm{~nm}$.

\subsection{Sodium caseinate preparation}

Whole ovine and caprine caseins were obtained from raw milk, via isoelectric precipitation following acidification to $\mathrm{pH} 4.25$ with $6 \mathrm{M} \mathrm{HCl}$ - according to the method of Sousa and Malcata (1998) with slight modifications. The mixture of caseins and whey was warmed to $37^{\circ} \mathrm{C}$, and held at that temperature for $30 \mathrm{~min}$. The caseins were recovered by filtration through a clean cloth, and washed several times with deionized water. The caseins were then resuspended in deionized water (to the initial volume), and $\mathrm{pH}$ was adjusted to 7.0 with $1 \mathrm{mM} \mathrm{NaOH}$. The suspension was allowed to equilibrate at $4{ }^{\circ} \mathrm{C}$ for at least $2 \mathrm{~h}$, freeze-dried and stored until use. 


\subsection{Enzymatic hydrolysis performance}

Whole caseinates were dissolved to a final concentration of $1 \%(\mathrm{w} / \mathrm{v})$ in $100 \mathrm{mM}$ phosphate buffer $(\mathrm{pH} 6.5)$, containing $0.1 \%(\mathrm{w} / \mathrm{v}) \mathrm{NaN}_{3}$ to prevent protein degradation by adventitious microflora, and allowed to stabilize at $30^{\circ} \mathrm{C}$. The reactions were started by addition of $450 \mu \mathrm{l}$ of each caseinate to $45 \mu \mathrm{l}$ of $\mathrm{EE}$ (which corresponds to $44 \pm 4 \mu \mathrm{g}$ of protein $/ \mathrm{ml})$. At different times, the reactions were quenched by addition of $500 \mu \mathrm{l}$ of $5 \%(\mathrm{w} / \mathrm{v})$ trichloroacetic acid (TCA). The samples were left to precipitate overnight at $4{ }^{\circ} \mathrm{C}$, and then centrifuged at $10,000 \mathrm{~g}$. The precipitates were redissolved in $450 \mu \mathrm{l}$ of sample buffers: (a) for urea polyacrylamide gel electrophoresis (urea-PAGE), the buffer was $62 \mathrm{mM}$ Tris- $\mathrm{HCl}$ ( $\mathrm{pH} 7.6$ ), containing $8 \mathrm{M}$ urea, $2.0 \%$ $(\mathrm{v} / \mathrm{v})$ 2-mercaptoethanol and $0.002 \%(\mathrm{w} / \mathrm{v})$ bromophenol blue, with $\mathrm{pH}$ adjusted with $1 \mathrm{M} \mathrm{NaOH}$, and with samples vortexed four times for $30 \mathrm{~s}$; (b) for tricine-sodium dodecylsulphate-PAGE (tricine-SDS-PAGE), the buffer was $62.5 \mathrm{mM}$ Tris- $\mathrm{HCl}(\mathrm{pH} 6.8)$, containing 2\% (w/v) SDS, $0.5 \%(\mathrm{v} / \mathrm{v}) 2$-mercaptoethanol, $0.002 \%$ (w/v) bromophenol blue and $10 \%(\mathrm{w} / \mathrm{v})$ glycerol, with $\mathrm{pH}$ adjusted with $1 \mathrm{M}$ $\mathrm{NaOH}$, and with samples heated at $100{ }^{\circ} \mathrm{C}$ for $5 \mathrm{~min}$.

Controls containing $\mathrm{Na}$-caseinate and $\mathrm{Na}$-azide, at the same concentrations but without addition of enzyme, were also sampled. Digestion of ewe's and goat's caseinates were also carried out with commercial animal rennet (Chris Hansen's, Copenhagen, Denmark), diluted so as to obtain the same coagulation time with EE.

In all cases, samples were dissolved in urea buffer.

\subsection{Electrophoretic analysis}

Electrophoresis were performed using a Mini Protean III cell (Bio-Rad Laboratories, Hercule, CA, USA). Urea-PAGE was according to Shalabi and Fox (1987); gels were pre-run at $50 \mathrm{~mA}$ for $10 \mathrm{~min}$, and after sample loading, the power supply was set at $100 \mathrm{~V}$ at the stacking gel, and then increased to $200 \mathrm{~V}$ at the resolution gel.

Tricine-SDS-PAGE was according to Shägger and von Jagow (1987): after sample loading, the power supply was set at $30 \mathrm{~V}$ at the stacking gel, then increased at $15 \mathrm{~V}$ per min for four times, and finally maintained between 90 and $100 \mathrm{~V}$.

Gels were stained with Coomassie Blue G-250 (Bio-Rad Bulletin, 2003). Quantification of intact caseins and polypeptides was done by gel scanning followed densitometry, using the software Scion Image Beta v. 4.02 for Windows (Scion Corporation, Frederick, MA, USA).

\subsection{Electroblotting preparation}

After Tricine-SDS-PAGE, the peptides were transferred onto a polyvinylidene difluoride (PVDF) membrane by electroblotting in $10 \mathrm{mM}$ 3-(cyclohexylamino)-1-propanesulfonic acid (CAPS) containing 10\% (v/v) methanol $(\mathrm{pH}$ $11)$, at $500 \mathrm{~mA}$ for $1 \mathrm{~h}$.

\subsection{Chemical sequencing}

$\mathrm{N}$-terminal amino-acid sequences of the protein bands recovered via electroblotting were determined by Edman degradation, using an automated pulsed liquid-phasepeptide sequencer (Applied Biosystem 477 A sequencer, Foster City CA, USA). Partial sequences obtained were checked against known sequences of caseins, in order to identify the cleaved peptide bonds. Sequence homology searches were performed using the BLAST network services (Altschul et al., 1997).

\section{Results and discussion}

\subsection{Enzyme extracts - protein quantification, milk clotting activity and endopeptidasic activity}

The EE obtained from fresh flowers of $S$. marianum, and partially purified by gel filtration ( $\mathrm{pH}$ 3.0) displayed a protein content of $264 \pm 4 \mathrm{mg} / 1$, a clotting activity of $0.083 \pm 0.003 \mathrm{RU} / \mathrm{ml}$ and an endopeptidasic activity of $1.50 \times 10^{-5} \mathrm{IU}$.

As reported elsewhere (Vairo Cavalli et al., 2005) the nature of proteolytic activity associated with MCA is due to aspartyl endopeptidases. On the other hand, when endopeptidase inhibitors (PMSF - a serine protease inhibitor, E-64 - a cysteine protease inhibitor, and pepstatin $\mathrm{A}$ - an aspartic protease inhibitor) were preincubated with the EE, only the latter promoted inhibition of milk clotting activity. Recall that pepstatin is one of the most specific inhibitors known in enzymology, and is highly selective for aspartic peptidases (Dunn, 2001).

\subsection{Caprine caseinate}

\subsubsection{Urea-PAGE analysis}

It is known that only four genotypes of caseins exist, so the heterogeneity apparent in electrophoresis is due to effects of post-translational processing, alternative splicing of gene product or genetic polymorphisms (Recio, PerezRodriguez, Amigo, \& Ramos, 1997). Recall that the American Dairy Science Association Committee on Nomenclature and Classification, back in 1984, proposed that the nomenclature developed for bovine caseins, viz. $\alpha_{\mathrm{s} 1^{-}}, \alpha_{\mathrm{s} 2^{-}}, \beta$ - and $\kappa$-caseins, be adopted for milk proteins of other species (Ginger \& Grigor, 1999).

A typical urea-PAGE electrophoregram of caprine caseinate, and its fractional degradation by $\mathrm{EE}$ is depicted in Fig. 1A. The group of bands with the lowest electrophoretic mobility therein is accounted for by $\beta$-casein. Conversely, the group of bands with the highest electrophoretic mobility is associated with $\alpha_{\mathrm{s}}$-casein (Silva \& Malcata, 2000).

Sodium caseinate was hydrolyzed by EE to yield band (a) - which exhibits an intermediate mobility between $\beta$ and $\alpha_{\mathrm{s} 2}$-casein, and which can be seen after $1 \mathrm{~h}$ of digestion and becomes more intense as reaction time elapsed (lanes 


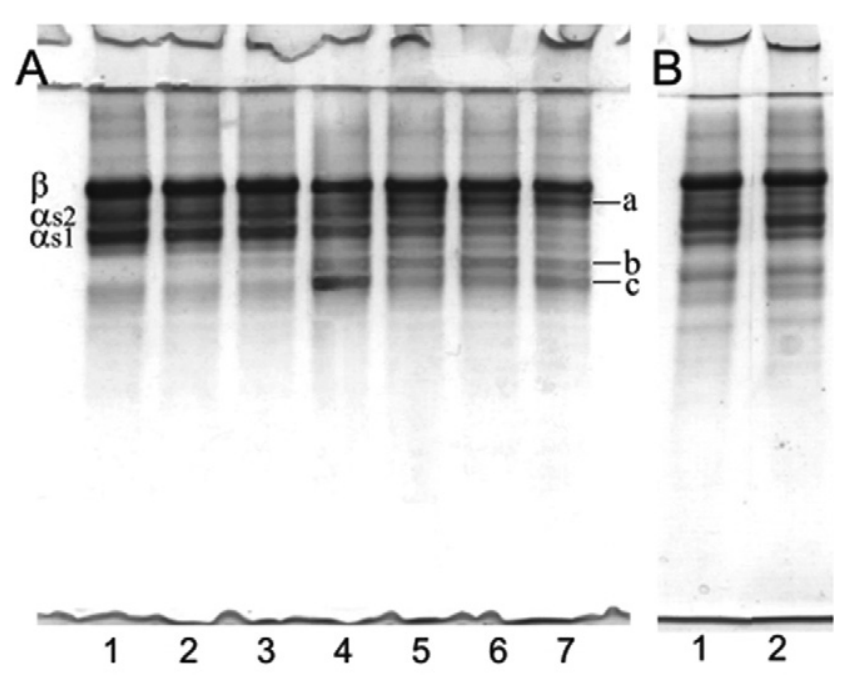

Fig. 1. Urea-PAGE electrophoretogram (resolution gel of $T=12.5 \%$ and $C=4 \%, \mathrm{pH} 8.9$, overlaid by stacking gel of $T=4 \%, C=3 \%, \mathrm{pH} 7.6$ ). A degradation patterns of goat's caseins by EE; lanes 1-7: caseins after incubation for $0,30 \mathrm{~min}, 1 \mathrm{~h}, 3 \mathrm{~h}, 6 \mathrm{~h}, 12 \mathrm{~h}$, and $24 \mathrm{~h}$, respectively. B degradation patterns of caprine caseinate by commercial bovine curdle; lanes 1-2: caseins after incubation for $0 \mathrm{~min}$ and $24 \mathrm{~h}$.

3-7 in Fig. 1A). A pair of bands of higher electrophoretic mobility - denoted as bands (b) and (c), in lanes 2-7 of Fig. 1A, were also produced; band (b) was first visible by $30 \mathrm{~min}$, became much more intense until $3 \mathrm{~h}$, and remained as such until $24 \mathrm{~h}$ of reaction. On the other hand, band (c) looked very intense by $3 \mathrm{~h}$ of hydrolysis, but vanished as time elapsed. The densitograms corresponding to the bands obtained by urea-PAGE are shown in Fig. 2A. Caprine $\beta$ casein was degraded up to $40 \%$ (Fig. 2A), whereas caprine $\alpha_{\mathrm{s} 1}$-casein was hydrolyzed up to $68 \%$, by $24 \mathrm{~h}$ of incubation. These results do not agree with those by Sousa and Malcata (1998) for caprine Na-caseinate hydrolyzed at pH 6.5 by enzymatic extracts of flowers of $C$. cardunculus (Asteraceae), and those by Silva and Malcata (2000) pertaining to degradation of caprine Na-caseinate at $\mathrm{pH} 6.8$ with purified cardosins A and B. The breakdown patterns of bovine Na-caseinate by EE of S. marianum (Vairo Cavalli et al., 2005) showed a greater hydrolysis degree of $\beta$ casein, as well as very different profile relative to obtained with caprine Na-caseinate.

The kinetics of hydrolysis, measured as the decrease in area of densitogram peaks are apparent in Fig. 3. The rate of breakdown was similar for both caseinates during the first $3 \mathrm{~h}$ of reaction. These results are consistent with those reported by Sousa and Malcata (1998), who promoted reaction catalyzed by aqueous extracts of dry flowers of C. cardunculus, at $\mathrm{pH}$ 5.9. However, as hydrolysis proceeded, $\alpha_{\mathrm{s} 1}$-casein was hydrolyzed to a greater extent than $\beta$-casein.

Hydrolysis of goat's caseinate was also carried out separately with commercial bovine curdle and with EE of flowers of $S$. marianum under identical reaction conditions. The results produced by urea-PAGE are also shown in Fig. 1A and B. It can be observed that the commercial
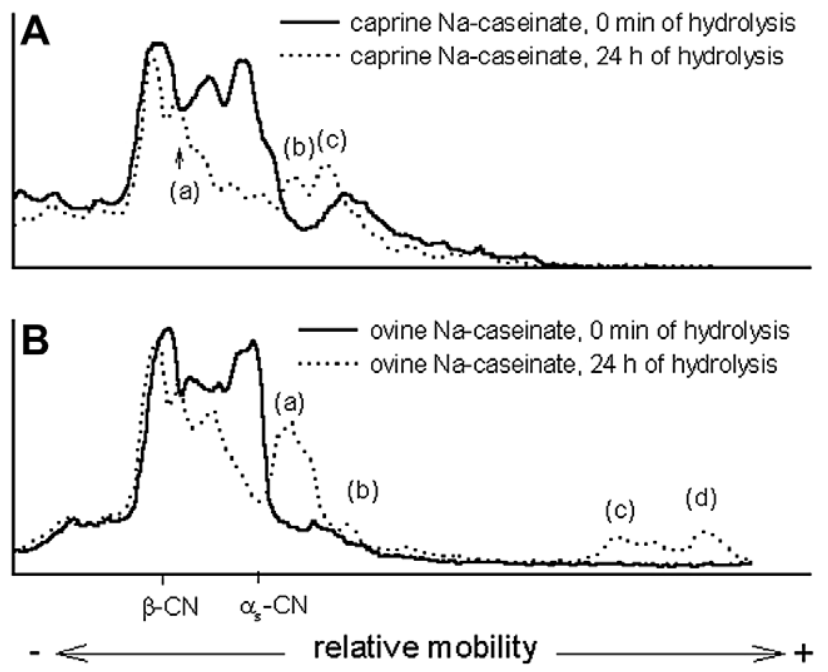

Fig. 2. Densitogram analysis of bands obtained by urea-PAGE of (A) caprine Na-caseinate and of (B) ovine Na-caseinate.

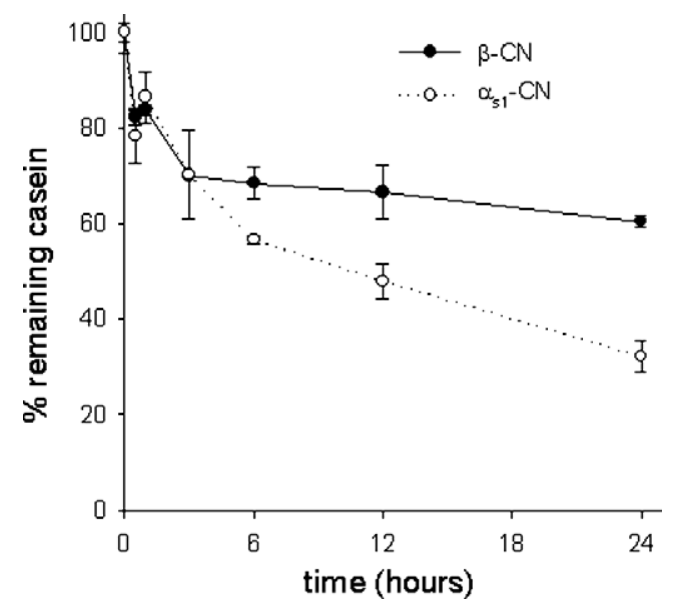

Fig. 3. Kinetics of hydrolysis of caprine $\alpha_{\mathrm{s} 1^{-}}$and $\beta$-caseins.

bovine curdle did not produce any observable effect on the two more important fractions of casein, but it partially hydrolyzed the proteins/peptides associated with bands with mobility between those of $\alpha_{s 1}$ - and $\beta$-caseins - which corresponds to $\alpha_{\mathrm{s} 2}$-casein. On the other hand - and as already observed in Fig. 1A, EE produced extensive degradation of $\alpha_{\mathrm{s}}$-caseins but only a slighter degradation of $\beta$ casein.

\subsubsection{Tricine SDS-PAGE analysis}

The results obtained by tricine SDS-PAGE of hydrolyzed goat's caseinate is shown in Fig. 4. Only one important and defined band (a), characterized by $15.0 \mathrm{kDa}$, appeared by $12 \mathrm{~h}$ of digestion - and became more intense by $24 \mathrm{~h}$. The N-terminal sequence of the peptide with the molecular weight of $14.4 \mathrm{kDa}$ was REQEELNV, which corresponds to the $\mathrm{N}$-terminus of $\beta$-casein. Studies including casein breakdown in caprine cheeses by animal rennet have also reported the presence of bands accounted for by $\beta$-casein fragments (Silva \& Malcata, 2000). 


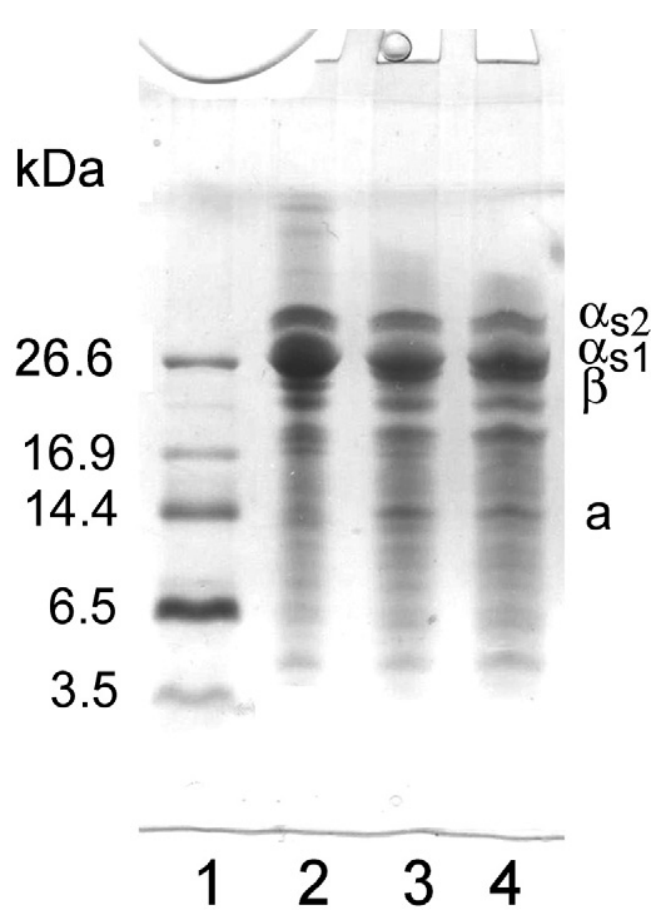

Fig. 4. Tricine SDS-PAGE electrophoretogram (resolution gel of $T=14.5 \%, C=3 \%$, overlaid by separating gel of $T=10 \%, C=3 \%$, and then by stacking gel of $T=4 \%, C=3 \%$ ). Degradation patterns of caprine caseins by EE; lane 1: polypeptide molecular weight markers (Bio$\mathrm{Rad})$ : bacitracin $(1.4 \mathrm{kDa})$, insulin $\mathrm{b}$ chain, oxidized $(3.5 \mathrm{kDa})$, aprotinin $(6.5 \mathrm{kDa}), \alpha$-lactalbumin $(14.4 \mathrm{kDa})$, myoglobin $(17.0 \mathrm{kDa})$ and triosephosphate isomerase $(26.6 \mathrm{kDa})$; lane 2 : intact casein; lanes 3-5: whole casein after $6 \mathrm{~h}, 12 \mathrm{~h}$ and $24 \mathrm{~h}$ of digestion, respectively. Proteins were stained with Coomasie Blue $\mathrm{G}$.

\subsection{Ovine caseinate}

\subsubsection{Urea-PAGE analysis}

The results of hydrolysis of ovine caseinate analysed by urea-PAGE are depicted in Fig. 5A. Two main groups of caseins can be identified - regions $\alpha_{\mathrm{s}^{-}}$and $\beta$-caseins; this observation is consistent with those previously reported by Richardson and Creamer (1976). The group with greater mobility corresponds to $\alpha_{\mathrm{s}}$-caseins, and may include several variants; such microheterogeneity comes, as previously discussed, from the degree of glycosylation and/or the degree of phosphorylation, in addition to actual genetic polymorphism (Chianese et al., 1996). The group with lower mobility corresponds to the region of $\beta$-casein - formed by two variants, $\beta_{1}$ and $\beta_{2}$, with differences in phosphorylation level (Sousa \& Malcata, 1998).

Although breakdown of ovine caseinate took place much slowlier than that of bovine counterpart (Vairo Cavalli et al., 2005), a region with bands of greater mobility than $\alpha_{\mathrm{s}}$-casein is visible as early as by $30 \mathrm{~min}$ (a). On the other hand, other bands appeared after $6 \mathrm{~h}$ of incubation and became thicker towards $24 \mathrm{~h}$. In the urea-PAGE densitogram (Fig. 2B), peaks (a-d) can be seen by $24 \mathrm{~h}$ of hydrolysis. A noticeable decrease of $\alpha_{\mathrm{s}}$-casein from 0 to $24 \mathrm{~h}$ of degradation can also be observed. After $24 \mathrm{~h}$ of

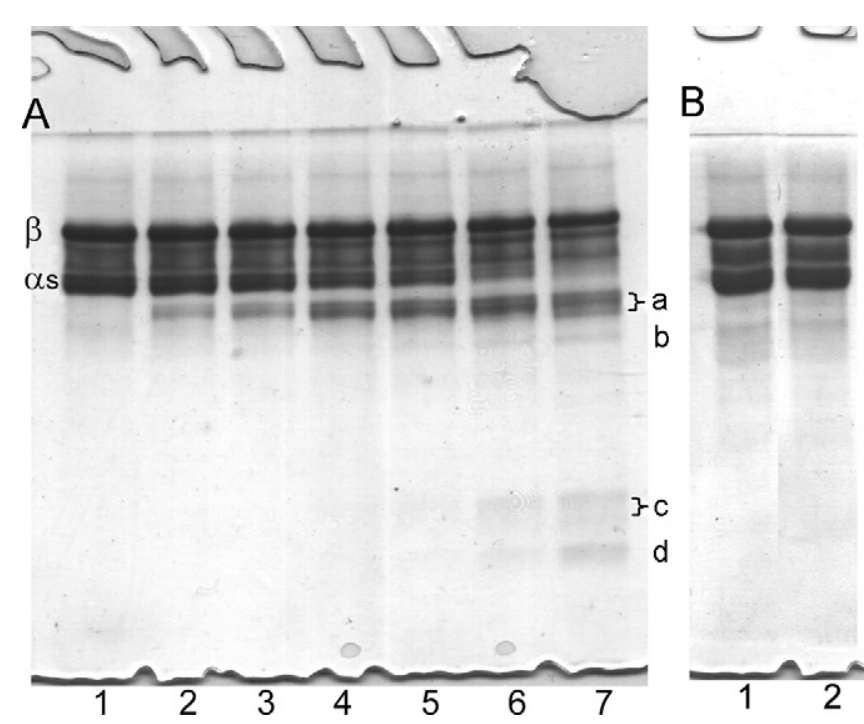

Fig. 5. Urea-PAGE electrophoretogram (resolution gel was $T=12.5 \%$ and $C=4 \%, \mathrm{pH} 8.9$, overlaid by stacking gel of $T=4 \%, C=3 \%$, $\mathrm{pH} 7.6$ ). A - degradation patterns of ewe's caseins by EE; lanes 1-7: caseins after incubation for $0,30 \mathrm{~min}, 1 \mathrm{~h}, 3 \mathrm{~h}, 6 \mathrm{~h}, 12 \mathrm{~h}$ and $24 \mathrm{~h}$, respectively. B degradation patterns of ovine caseinate by commercial bovine curdle; lanes 1-2: caseins after incubation for $0 \mathrm{~min}$ and $24 \mathrm{~h}$.

incubation, $\alpha_{s}$-casein was degraded by EE to $76 \pm 4 \%$, whereas $\beta$-casein was only degraded to $19 \pm 4 \%$. Electrophoresis analysis of water insoluble fractions from La Serena cheese - semi-hard Spanish ewe's milk cheese manufactured with extracts of $C$. cardunculus, showed that $\alpha_{\mathrm{s}}$-casein was less susceptible to proteolysis than $\beta$-casein (Roa, López, \& Mendiola, 1999). After ripening Serra da Estrela cheeses produced in Portugal from ovine milk curdled with extracts of flowers of $C$. cardunculus; were characterized by extensive hydrolysis of $\beta$ - and $\alpha_{\mathrm{s}}$-caseins, and essentially similar viz. $75 \%$ and $82 \%$, respectively (Macedo \& Malcata, 1997). Silva and Malcata (1999) reported that cardosin B degraded both ovine caseins, but not to the same extent; however, when whole ovine caseinate was degraded by cardosin $\mathrm{B}, \alpha_{\mathrm{s}}$-casein was more susceptible to proteolysis than $\beta$-casein, whereas the opposite behavior was observed when the isolated fractions were exposed to hydrolysis. In cheese-like systems, none of the highly susceptible peptide bonds of $\alpha_{\mathrm{s} 1}$-casein were found to be cleaved during the initial $24 \mathrm{~h}$ of ripening - neither by crude aqueous extracts of $C$. cardunculus or by purified cardosin A (Silva \& Malcata, 2005). Irigoyen et al. (2000) found that $\alpha_{\mathrm{s}}$-casein are more acutely hydrolyzed than $\beta$ caseins throughout ripening of ovine cheeses, that had been curdled with lamb artisan rennet, calf industrial rennet or a mixture of both. The clotting activity of the rennet used is one of the factors that has a major influence upon the degradation extent of caseins; similarly, the origin of the clotting enzyme used (from animal, microbial or plant sources) will constrain the proteolysis degree; plant and microbial clotting enzymes breakdown $\beta$-caseins faster than animal ones (Irigoyen et al., 2000). 
In attempts to compare degradation patterns, ovine caseinate was hydrolyzed with commercial bovine rennet and $\mathrm{EE}$, under identical conditions of reaction; the resulting electrophoregram is shown in Fig. 5B. By $24 \mathrm{~h}$ of hydrolysis, a region (a) and a band (b) close to the $\alpha_{\mathrm{s}}$-caseins can be visualized, and another region of dimmed band (c) and a band (d) but with much greater mobility can also be shown (Fig 5A). Electrophoresis of hydrolyzed caseinate (lane 2 in Fig. 5B), carried out for $24 \mathrm{~h}$ with commercial bovine rennet, displayed little difference with respect to the control (lane 1 in Fig. 5B); only a low intensity new band (e), of smaller mobility than $\beta$-casein, a band (f) and a region of bands $(\mathrm{g})$ with greater mobility - yet close to fraction $\alpha_{\mathrm{s}}$-caseins can be observed.

The kinetic of hydrolysis of ovine $\alpha_{\mathrm{s}^{-}}$and $\beta$-caseins carried out by the partially purified extract of flowers of $S$. marianum, are displayed in Fig. 6 As discussed above, $\alpha_{s}-$ casein was faster and more extensively degraded than $\beta$ casein - unlike the data reported by Sousa and Malcata (1998), who found similar rates of hydrolysis (until $3 \mathrm{~h}$ of reaction) for both ovine fractions when the reaction was effected by aqueous extracts ( $\mathrm{pH}$ 5.9) of dry flowers of $C$. cardunculus.

\subsubsection{Tricine SDS-PAGE analysis}

The results of tricine SDS-PAGE of hydrolyzed ewe's caseinate is shown in Fig. 7. After $12 \mathrm{~h}$, bands characterized by molecular weights of $18.9,16.5,11.2$ and $8.6 \mathrm{kDa}$ became more intense, while smaller peptide bands $(5.8$ and $4.3 \mathrm{kDa}$ ) appeared.

In what concerns specificity, the major cleavage site in $\alpha_{\mathrm{s} 1}$-casein was Leu99-Arg100 - as derived from N-terminal sequencing of the band featuring $14.4 \mathrm{kDa}$ [i.e. $\alpha_{\mathrm{s} 1^{-}}$ (f100- $\left.{ }^{*}\right)$. According to Sousa and Malcata (1998) and Silva and Malcata (2005), this peptide bound was not reported to be cleaved by aspartic peptidases of $C$. cardunculus; however, Lane, Fox, Johnston, and McSweeney (1997) found the peptide [f102-199] from bovine $\alpha_{\mathrm{s} 1}$-casein in the electrophoregrams of cheeses curdled with chymosin, as a band that increased in intensity throughout ripening.

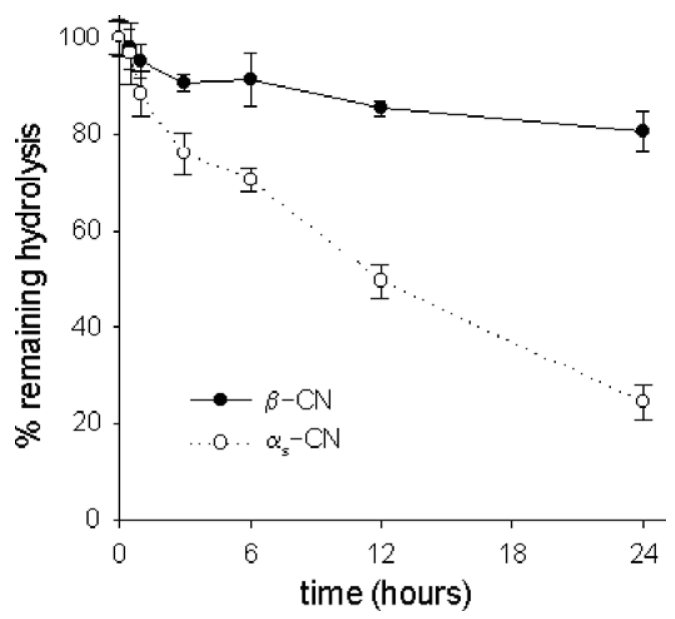

Fig. 6. Kinetics of hydrolysis of ovine $\alpha_{\mathrm{s}}$ - and $\beta$-casein.

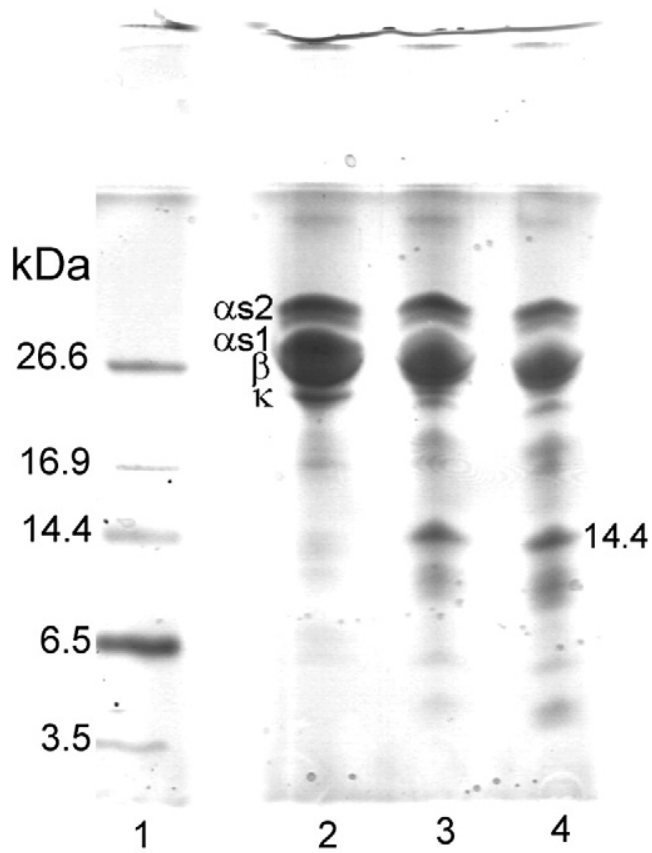

Fig. 7. Tricine SDS-PAGE electrophoretogram (resolution gel of $T=14.5 \%, C=3 \%$, overlaid by separating gel of $T=10 \%, C=3 \%$, and then by stacking gel of $T=4 \%, C=3 \%$ ). Degradation patterns of ovine caseins; lane 1: polypeptide molecular weight markers (Bio-Rad): bacitracin $(1.4 \mathrm{kDa})$, insulin $\mathrm{b}$ chain, oxidized $(3.5 \mathrm{kDa})$, aprotinin $(6.5 \mathrm{kDa}), \alpha$-lactalbumin $(14.4 \mathrm{kDa})$, myoglobin $(17.0 \mathrm{kDa})$ and triosephosphate isomerase $(26.6 \mathrm{kDa})$; lane 2 : intact casein; lanes 3-5: whole casein after $6 \mathrm{~h}, 12 \mathrm{~h}$ and $24 \mathrm{~h}$ of digestion, respectively. Proteins were stained with Coomasie Blue G.

\section{Conclusions}

Distinct peptide profile were observed in goat's and ewe's caseinates throughout hydrolysis brought about by extracts of $S$. marianum; however, lot caseinates underwent less extensive degradation than bovine caseins, for the same enzyme extract. On the other hand, caprine and ovine $\mathrm{Na}-$ caseinates were hydrolyzed more extensively with the plant extract than the same caseinates by calf commercial rennet, under the same conditions.

Caprine $\alpha_{\mathrm{s} 1^{-}}$and $\beta$-caseins were degraded up to $68 \%$, and $40 \%$, respectively during $24 \mathrm{~h}$ of incubation. Only one important and well-defined band - characterized by a molecular weight of $14.4 \mathrm{kDa}$, was observed by $12 \mathrm{~h}$ of hydrolysis, which is likely a fragment of goat's $\beta$-casein. By $24 \mathrm{~h}$ of incubation, ovine $\alpha_{\mathrm{s}^{-}}$and $\beta$-caseins were degraded up to $76 \%$ and $19 \%$, respectively.

In terms of specificity, the major cleavage site of ovine caseinate was Leu99-Arg100 of $\alpha_{\mathrm{s} 1}$-casein.

\section{Acknowledgements}

The authors are grateful to Dr. P. Veríssimo for making available the fluorogenic reagent. The authors also thank Tolbiac S.R.L. and Mr. J. Madarnas for supply of $S$. 
marianum seeds. Vairo Cavalli received a postdoctoral fellowship by CONICET. The present work was supported by grants from ANPCyT, CONICET and UNLP.

\section{References}

Altschul, S. F., Madden, T. L., Schäffer, A. A., Zhang, J., Zhang, Z., Miller, W., et al. (1997). Gapped BLAST and PSI-BLAST: A new generation of protein database search programs. Nucleic Acids Research, 25, 3389-3402.

Ariza-Espinar, L., Delucchi, G. (1998). 280 Asteraceae, parte 11. Tribu XI. Cardueae. In L. Ariza-Espinar (Ed.), Flora Fanerogámica Argentina (pp. 24-25). Córdoba: Pro Flora.

Barros, R. M., Ferreira, C. A., Silva, S. V., \& Malcata, F. X. (2001). Quantitative studies on the enzymatic hydrolysis of milk proteins brought about by cardosins precipitated by ammonium sulfate. Enzyme and Microbial Technology, 29, 541-547.

Bradford, M. M. (1976). A rapid and sensitive method for the quantitation of microgram quantities of proteins utilizing the principle of protein dye binding. Analytical Biochemistry, 72, 248-254.

Chianese, L., Garro, G., Mauriello, R., Laezza, P., Ferranti, P., \& Addeo, F. (1996). Occurrence of five alpha s1-casein variants in ovine milk. Journal of Dairy Research, 63, 49-59.

Domingos, A., Xue, Z. T., Guruprasad, K., Clemente, A., Blundell, T., Pais, M. S., et al. (1998). An aspartic proteinase from flowers of Centaurea calcitrapa. Purification, characterization, molecular cloning, and modelling of its three-dimensional structure. Advances in Experimental Medicine and Biology, 436, 465-472.

Dunn, B. M. (2001). Determination of protease mechanism. In R. Beynon \& J. S. Bond (Eds.), Psroteolytic enzymes: A practical approach (2nd ed., pp. 83-86). New York: Oxford University Press.

Ginger, M. R., \& Grigor, M. R. (1999). Comparative aspects of milk caseins. Comparative Biochemistry and Physiology B, 124, 133-145.

International Dairy Federation (1992). Bovine rennets: determination of total milk-clotting activity. Brussels: IDF (FIL-IDF Standard no. 157).

Irigoyen, A., Izco, J. M., Ibáñez, F. C., \& Torre, P. (2000). Evaluation of the effect of rennet type on casein proteolysis in an ovine milk cheese by means of capillary electrophoresis. Journal of Chromatography A, 881, 59-67.

Lane, C. N., Fox, P. F., Johnston, D. E., \& McSweeney, P. L. H. (1997). Contribution of coagulant to proteolysis and textural changes in cheddar cheese during ripening. International Dairy Journal, 7, 453-464.

Macedo, A. C., \& Malcata, F. X. (1997). Hydrolysis of $\alpha_{\mathrm{s}^{-}}$and $\beta$-caseins during ripening of Serra cheese. Food Chemistry, 58, 43-48.

Recio, I., Perez-Rodriguez, M. L., Amigo, L., \& Ramos, M. (1997). Study of the polymorphism of caprine milk caseins by capillary electrophoresis. Journal of Dairy Research, 64, 515-523.

Reis, P. M., Lourenço, P. L., Domingos, A., Clemente, A. F., Pais, M. S., \& Malcata, F. X. (2000). Applicability of extracts from Centaurea calcitrapa in ripening of bovine cheese. International Dairy Journal, 10, 775-780.

Richardson, B. C., \& Creamer, L. K. (1976). Comparative micelle structure. V. The isolation and characterization of the major ovine caseins. New Zealand Journal of Dairy Science and Technology, 11, $46-53$.
Roa, I., López, M. B., \& Mendiola, F. J. (1999). Residual clotting activity and ripening properties of vegetable rennet from Cynara cardunculus in La Serena cheese. Food Research International, 32, 413-419.

Shägger, H., \& von Jagow, G. (1987). Tricine-sodium dodecyl sulphatepolyacrylamide gel electrophoresis for the separation of proteins in the range of 1-100 kDa. Analytical Biochemistry, 166, 368-379.

Shalabi, S. I., \& Fox, P. F. (1987). Electrophoretic analysis of cheese, comparison of methods. Irish Journal of Food Science and Technology, $11,135-151$.

Silva, S. V., \& Malcata, F. X. (1999). On the activity and specificity of cardosin B, a plant proteinase, on ovine caseins. Food Chemistry, 67, 373-378.

Silva, S. V., \& Malcata, F. X. (2000). Comparative catalytic activity of two plant proteinases upon caprine caseins in solution. Food Chemistry, 71, 207-214.

Silva, S. V., \& Malcata, F. X. (2005). Partial identification of watersoluble peptides released at early stages of proteolysis in sterilized ovine cheese-like systems: Influence of type of coagulant and starter. Journal of Dairy Science, 88, 1947-1954.

Sousa, M. J., \& Malcata, F. X. (1998). Proteolysis of ovine and caprine caseins in solution by enzymatic extracts from flowers of Cynara cardunculus. Enzyme and Microbial Technology, 22, 305-314.

Tamer, I. M. (1993). Identification and partial purification of a novel milk clotting enzyme from Onopordum turcicum. Biotechnology Letters, 15, 427-432.

Vairo Cavalli, S., Claver, S., Priolo, N., \& Natalucci, C. (2005). Extraction and partial characterization of a coagulant preparation from Silybum marianum flowers. Its action on bovine caseinate. Journal of Dairy Research, 72, 271-275.

Veríssimo, P. C., Esteves, C., Faro, C. J., \& Pires, E. M. (1995). The vegetable rennet from Cynara cardunculus $\mathrm{L}$. contains two proteinases with chymosin-like and pepsin-like specificities. Biotechnology Letters, 17, 614-645.

Veríssimo, P., Faro, C., Moir, A. J., Lin, Y., Tang, J., \& Pires, E. (1996). Purification, characterization and partial amino acid sequencing of two new aspartic proteinases from fresh flowers of Cynara cardunculus L. European Journal of Biochemistry, 235, 762-768.

Visser, S. (1993). Symposium: Proteolytic enzymes and cheese ripening. Proteolytic enzymes and their relation to cheese ripening and flavor: an overview. Journal of Dairy Science, 76, 329-350.

Walstra, P., Geurts, T. J., Noomen, A., Jellema, A., \& van Boekel, M. A. J. S. (1999). Dairy technology: Principles of milk properties and processes. New York: Marcel Dekker, Chapter 1 (pp. 14-15).

\section{Web references}

Bio-Rad Bulletin 2423. (2003) Bio-Safe ${ }^{T M}$ Coomassie Stain. http:// www.bio-rad.com/LifeScience/pdf/Bulletin_2423.pdf.

Dayenoff, P., Ochoa, M. A. \& Domínguez, G. (2002). Efecto del nivel de alimentación sobre la producción lechera, en cabras criollas. Estación Experimental Agropecuaria Rama Caída, Instituto Nacional de Tecnología Agropecuaria, Argentina http://www.inta.gov.ar/ramacaida/info/documentos/caprinos/prodlech.htm.

Dulce, E. (2006). Facultad de Agronomía, Universidad de Buenos Aires, Argentina. www.agro.uba.ar/produccion ovina/memo_jornada.pdf.

Estación Experimental Agropecuaria Chubut, Instituto Nacional de Tecnología Agropecuaria, Argentina (2006). www.inta.gov.ar/chubut/investiga/lineas.htm. 